\title{
Macrozoobenthos Soft Soils of the Far Eastern Marine Biosphere Reserve
}

\author{
Latypov Yuri Yakovlevich \\ A.V. Zhirmunsky Institute of Marine Biology, FEB RAS, Vladivostok 690059, Russia \\ E-mail:1tpv@mail.ru
}

Received: December 24, 2012 Accepted: January 21, $2013 \quad$ Published: June 24, 2013

doi:10.5296/jee.v4i1.2944 URL: http://dx.doi.org/10.5296/jee.v4i1.2944

\begin{abstract}
This study analyzed the composition and distribution of the macrozoobenthos of the soft soils of the Far Eastern Marine Biosphere Reserve. Found 176 species, classified in six groups: Polychaeta, Bivalvia, Gastropoda, Cumacea, Isopoda, Echinodermata. The greatest variety of typical for polychaete worms (67 species) and bivalves (48 species). Found that the coefficient of variation in the ratio of the number of major taxonomic groups for soft ground of sublittoral reserve (1.02) is slightly higher than for water areas with domination of the soft soils in northern latitudes (area of Spitsbergen and the North Sea), and is closer to that of the bays and coves of the South China Sea and the North-East coast of Australia.
\end{abstract}

Keywords: Macrozoobenthos, Community, Species composition, Structure, Soft soils, Marine reserve 


\section{Introduction}

Composition and distribution of the benthic fauna of the soft soils of the Far Eastern Marine Biosphere State Nature Reserve are still not sufficiently explored. In 1963, the hydrobiological monitoring in this area were conducted only in waters of the bays Sivuch'ya and Kalevala (Mikulich \& Biryulina, 1970). Expedition of the Pacific Research Institute of Fisheries and Oceanography (TINRO), in the 70 's, who studied the patterns of distribution of benthos in the Peter the Great Gulf, received data for six stations, located south of the island Furugelm (Klimova, 1971; Pavluchkov, 1975). Research on the southern section of the reserve is conducted by specialists of the Institute of Marine Biology (IMB) in 1980-1987 to inventory the populations of benthic invertebrates and explore some factors were mostly not published or contains a little informative and hard-to-reach theses (Gulbin \& Ozolinsh, 1986, 1989; Ozolinsh, 1986). In 1996, IMB was the first integrated ecological expedition in the South-western part of the Peter the Great Gulf and the mouth of the Tumannaya river. The main objective of research was to examine hydrological and hydrochemical parameters, the level of contamination, and the condition of the benthic and pelagic communities (Belan, 2000; Orlova et al., 2000; Shulkin \& Moshchenko, 2000) but the data on the composition and structure of the benthic communities of the soft soils for all areas of the reserve are not yet available. The purpose of this article to fill a gap in the characterization of this faunal composition and main regularities of distribution of macrobenthos bottom-dwelling communities of soft soils.

\section{Material and Method}

\subsection{Study Area and Sampling Parameters}

Marine Reserve area is 64311.6 hectares $\left(643.116 \mathrm{~km}^{2}\right)$ is about $10 \%$ of the Peter the Great Gulf of the Japan Sea. It would seem, is not very much, but at the same time, the reserve area is superior to the territory of those States, such as Bahrain, Liechtenstein, Malta and two dozen others. The island and free-standing sea rock outcrops form columnar rocks - kekura occupy only about $1.5 \%$ of the area of the reserve, the rest-area (actually, reserve, named after the Marine.-Special aesthetic, scientific and historical value reserve. a total of 10 islands and more than 20 smaller islets, rocks and kekuras, often do not have their own names on the map. the largest island - Bol'shoi Pelis, its area is about 410 acres (Figure 1).

In 2006-2008, 2010, took place the hydrobiological shooting on soft soil at 119 stations and cuts in the reserve and surrounding areas 9 areas (Figure. 2). Sampling conducted from June to September from on board the $\mathrm{m} / \mathrm{v}$ "Professor Nasonov"and "Vnimatel'nyi". Tests chose of grab Van-Wines with an area of $0.25 \mathrm{~m}^{2}$ at a depth of $40 \mathrm{~m}$, furthermore, at each station, produced records of macrobenthos in autonomous diving gear with square $5 \mathrm{~m}^{2}$. Soil elutriate on a sieve with mesh $0.1 \mathrm{~mm}$.

In the laboratory determined the species composition and quantity indicators of abundance of benthos (biomass and density of each species and systematic group, total biomass and abundance). A lot of large organisms determined to slash at the chemist's scales accurate to $10 \mathrm{mg}$, small-on torsion scales to within $1 \mathrm{mg}$. Before weighing the animal on the filter paper 
in the drained for $1 \mathrm{~min}$. All data measured on area $1 \mathrm{~m}^{2}$. Coefficient of variation in the ratio of the number of major taxonomic groups were determined by the formula $E=(m+c) / r$, where $\mathrm{m}$ is the number of species of mollusks, c - crustaceans, and $\mathrm{p}$ - polychaetes, registered in the area tests (Udalov et al., 2006), for statistical analysis and determining the level of affinity communities used the program Statistica 6.0.

\section{Results and Discussion}

\subsection{A Soft Soils}

In subtidal bays and the at island water area of the Reserve distributed soft soils. They are primarily silted to a greater or lesser extent by fine sandstones, small and medium-sized psammites. In the central parts of the Bay at a depth of more than $10 \mathrm{~m}$ of siltstones and silt accumulate psammites. In coastal regions, at a depth of 5-9 m, found, ground, mixed soils containing small boulders, small and medium-sized specks of gravel and bat "rakushi" (seashell).

\subsection{Composition of the Benthic Fauna}

As part of the sublittoral macrozoobenthos of soft soils registered 176 registered species six taxonomic groups: Polychaeta, Bivalvia, Gastropoda, Cumacea, Isopoda, Echinodermata , (Figure 3, Table 1). By number of species dominated by polychaetes (67 species), bivalves (48) and gastropods (23), from the total list of species respectively, 38.1, 27.3 and 13.1\%. The other groups included from 9 to 17 species. The greatest variety, at least 50 species was characterized by fauna on bays Sivuch'ya and island Furugelm. Less than 20 species met in the bay of Nerpich'ya. The total biomass of benthos in the average of $40.39 \mathrm{~g} / \mathrm{m}^{2}$, varying from 0.05 up to $80.78 \mathrm{~g} / \mathrm{m}^{2}$. Benthos density varied from 3.5 to $1638 \mathrm{ind} / \mathrm{m}^{2}$. Enhanced biomass $\left(65.39 \mathrm{~g} / \mathrm{m}^{2}\right.$ with a density of $\left.1638 \mathrm{ind} / \mathrm{m}^{2}\right)$ was observed among the foronid on Furugelm Island. There was the greatest number of echinoderms $\left(20 \mathrm{ind} / \mathrm{m}^{2}\right.$ with biomass-50.09 g/ $\mathrm{m}^{2}$ ). One species of gastropoda Erginus puniceus, and two bivalves Macoma golikovi and Mya japonica was first sighted in the waters of the Marine Reserve.

The average number of species encountered on the station is 12.3. The average number of species in a sample (of grab) equal to 8.2. The number of species in the sample is clearly and significantly associated with the number of specimens (Figure 4). Note the value for the small number of specimens and more species from island Stenina. Granulometric variety of soil samples were taken from small boulders and gravel on silted sand-probably can find enough room for the existence of more species, which leads to a reduction in individuals inhabiting this biotope. Increase in species diversity and low density of organisms characterized the environmental features of tropical macrobenthos communities (Alongi, 1989; Reise, 1991; Latypov, 2011). A significant increase in the number of individuals in terms of the number of species of the island Furugelm, compared with that of other similar areas of the reserve, will likely show an optimal abiotic condition for existence of macrobenthos community in the island. 


\subsection{Community Structure}

By frequency of occurrence was the starfish Patiria pectinifera, spread everywhere, bivalve Acila insignis, $77.7 \%$ of stations in met ophiura Ophiura sarsi - 66.6\%, isopoda Gnorimosphaeroma ovatum $-55.5 \%$ and crustaceans - up to $40 \%$,. Crustaceans are common in all areas of the reserve in $75 \%$ of stations, but only $54 \%$ of samples at a maximum density of $52 \mathrm{ind} / \mathrm{m}^{2}$, and biomass of $0.89 \mathrm{~g} / \mathrm{m}^{2}$. Polychaetes in general though were common in all areas and stations, but rarely had more than $30 \%$ of the total mass of the samples (Table 2). The maximum biomass of echinoderms $\left(64.426 \mathrm{~g} / \mathrm{m}^{2}\right)$, polychaetes $\left(13.662 \mathrm{~g} / \mathrm{m}^{2}\right)$ and bivalve Acila $\left(2.207 \mathrm{~g} / \mathrm{m}^{2}\right)$ was found in island Furugelm at assorted little silted sand at a depth of 21 m. Density of settlement macrobenthos on soft soil, varied from 14 to $925 \mathrm{ind} / \mathrm{m}^{2}$; its main part at most stations were polychaetes from 14 up to $90 \%$.

Table 2. Rate of occurrence of species and taxonomic groups

\begin{tabular}{|l|l|l|l|}
\hline Taxon & Rate of occurrence, $\%$ & Biomass, $\mathrm{g} / \mathrm{m}^{2}$ & Density, ind $/ \mathrm{m}^{2}$ \\
\hline Acila insignis & 77.7 & $2.308 \pm 2.8$ & $5.75 \pm 9.1$ \\
\hline Ophiura sarsi & 66.6 & $0.515 \pm 0.7$ & $7.6 \pm 12.7$ \\
\hline Cumacea & 60 & $0.165 \pm 0.4$ & $14.07 \pm 9.1$ \\
\hline Polychaeta & 30 & $0.593 \pm 1.2$ & $22.25 \pm 32.1$ \\
\hline Echinodermata & 100 & $14.996 \pm 24.7$ & $3.5 \pm 5.4$ \\
\hline
\end{tabular}

Dominating the soft soil of the surveyed area macrozoobenthos bivalve $A$. insignis, ophiura $A$. sarsi and polychaete S. armiger are common in the South-western part of the Peter the Great Gulf and are the dominants of the Pos'yet bay (Klimova, 1980), of estuary area Tumannaya river (Belan, 2000) and previously were noted for the water area Marine reserve (Ozolinsh, 2002).

Coefficient of variation in the ratio of the number of major taxonomic groups of soft soils for subtidal reserve is 1.02 . This is somewhat higher than for water areas with domination of the soft soils in northern latitudes (0.24-0.82-area of Spitsbergen and the North Sea, Laudien et al., 2004), and is closer to that of the bays and coves of the South China Sea and the coast of North-Eastern Australia (0.73-1.24, Dittmann, 1995; Udalov et al., 2006), and Troitsa bay (0.9) at the Peter the Great Gulf (Galysheva \& Christoforova, 2008). Noted the predominance of polychaetes on other groups of invertebrates throughout the reserve. On some latitudinal trends-topping position above polychaetes molluscs and crustaceans in the soft soils mentioned earlier (Reise, 1991; Weslawski et al., 2003; Udalov et al., 2006). Optimal abiotic conditions for diverse invertebrate fauna in the reserve were formed, apparently, Sivuch'ya bay, where almost half of the recorded species (43\%) and bivalves and $50.1 \%$ of polychaetes. 
The presence of echinoderms of $58.8 \%$ at the bottom in the water area of the island is probably a fake spread in the area, the less the soil mixed with sand silted "rakushi". The settlements marked the highest density of island Furugelm.

According to the degree of similarity of species composition of macrobenthos community in the eastern section of the reserve allocated (Maldane sarsi + Alveinus ojianus), covering both mainland and island bay; community bay island (Dipolydora cardalia + Ophiura sarci); and the community of open bays and coastal waters (Polychaeta + Acila insignis) (Figure 5).

The most likely factors determining the distribution of benthos in the soft soil of the Marine Reserve is the type of bottom sediments and indicated temperatures. All the fauna of the macrobenthos has an aggregated micro distribution. Patchy distribution of calcaneal mats polychaete $S$. armiger, Onuphis shirikishinaiensis and ophiuroids O. sarsi (common in the square from several $\mathrm{m}^{2}$ up to several tens $\mathrm{m}^{2}$ ) leads to aggregation of crustaceans and polychaetes, inhabiting these mats (Ozolinsh, 1992).

\section{Acknowledgements}

The author is grateful to his colleagues I.N. Budin, A.G. Goloseev, S.Sh. Dautov, A. A. Kepel', M.V. Malyutina, M.I. Nekrasova, N.I. Prokhorov, N.I. Selin, Yu.A. Trebuhova and L.A. Tcareva for their assistance with field studies, identification of species and valuable comments to the manuscript of the article. Work carried out under of grant "The biodiversity of marine benthic communities of soft soil DVMBSNR: monitoring, problems of preservation and restoration", N. 09-I-A23-08.

\section{References}

Alongi, D. M. (1989). Ecology of tropical soft-bottom benthos; a review with emphasis on emerging concepts. Revista de Biologia Tropical, 37, 85-100.

Belan T. A. (2000). Macrozoobenthos of Soft Bottom at Water Area from Mouth of Tumannaya River up the Furugelm Island (the Peter the Great Bay). In Ecological Condition and Biota of Southwest Part of the Peter the Great Bay and Mouth of the Tumannaya River. Vladivostok, Dalnauka, 1, 147-167.

Dittmann, S. (1995). Benthos structure of tropical tidal flats of Australia. Hielgolander Meerrsunthers, 49, 539-551.

Galysheva, Yu. A., \& Hristoforova N. K. (2008). Composition and quantitative distribution macrobenthos sublittoral Troitsy Bay, Posyet Bay. In Current status of living aquatic resources: materials of scientific conference devoted to 70-th anniversary of S.M. Konovalov, $1-19$.

Gulbin, V. V., \& Ozolinsh, A. V. (1986). Metodika uchetadonnyh zhivotnyh v morskih zfpovednikah. Tezisy dokladov sovetsaniya po problemam kadastra zhivotnyh. Moscow, 2, 445-446. (In Russian)

Gulbin, V. V.. \& Ozolinsh, A. V. (1989). Hydrobiological studies in the far eastern marine reserve: results and perspectives. In Gidrobiological issledovania in national parks. Theses 
Vsesjuznogo soveshaniya, 47-48. (In Russin).

Klimova, V. L. (1971).Quantitative benthos distribution of Peter the great Bay (Japan Sea) in the summer of 1970 г. Trudy VNIRO, 87, 97-104. (In Russian).

Klimova, V. L. (1980). Bottom fauna of the Gulf Posyet//Coastal plankton and benthos northern part of sea of Japan. Vladivostok: DVNC AN USSR, 20-30. (In Russian).

Latypov, Y. Ya. (2011). Scleractinian corals and reefs of Vietnam as a part of the pacific reef ecosystem. Open Journal of Marine Science, 1, 50-68. http://dx.doi.org/10.4236/ojms.2011.

Laudien, J., Herrmann, M., \& Arntz, W. E. (2004). Soft bottom community structure and diversity in Kongsfjorden (Slavbard). Berichte zur Polar-und Meersforschung, 492, 91-102. http://dx.doi.org/10.3354/meps08045

Mikulich, L. V., \& Biryulina, M. G. (1970). Some questions of hydrology and the bottom fauna of Posyet Bay. Trudy. DVNIGMI, 30, 300-316. (In Russian).

Orlova, N. Yu., Selina, M. S., \& Stonik, I. V. (2000).Phytoplankton of Mouth of Tumannaya River and of Adjacent Areas of the Peter the Great Bay. In Ecological Condition and Biota of Southwest Part of the Peter the Great Bay and Mouth of the Tumannaya River. Vladivostok, Dalnauka, 1, 129-146.

Ozolinsh, A. V. (1992). Polychaete community structure of the far Eastern Sea reserve in Peter the great Bay. In Polychaeta and their ecological value. Sankt-Peterburg: ZIN RAN, 157-162. (In Russian).

Ozolinsh, A.V. (2002). Seasonal dynamics of communities macrobenthos soft soil sublittoral of Peter the Great Bay, Sea of Japan. Russian Journal of Marine Biology, 28, 262-271.

Reise, K. (1991). Macrofauna in mud and sand of tropical and temperate tidal flats. In Ducrotoy J. P., \& Elliott M (Eds.), Estuaries and Coast: Spatial and temporal Intercomparisons (pp. 211-216). Olsen and Olsen, Fredensborg.

Shulkin, V. M., \& Moschenko, A. V. (2000). Level of Pollution and Factor Determining Content of Pollution in Bottom Sediment in the Mouth Area of Tumannaya River. In Ecological Condition and Biota of Southwest Part of the Peter the Great Bay and Mouth of the Tumannaya River. Vladivostok, Dalnauka, 1, 76-85.

Udalov, A. A., Britaev T. B., \& Thanh N. T. H. (2006). A Macrobenthos Features of Soft Soil Sublittoral of Nha Trang Bay (Viet Nam, South China Sea). Oceanology, 46, 518-526.

Weslawski, J. M., Wlodarska-Kowalczuk, M., \& Legezynska, J. (2003). Occurrence of soft bottom macrofauna along the depth gradient in High Arctic, $79^{\circ}$ N. Polish Polar Research, 34, 73-88. 
Table 1. Distribution of invertebrate species in various parts of the Marine Reserve

\begin{tabular}{|c|c|c|c|c|c|c|c|c|c|}
\hline Species & 1 & 2 & 3 & 4 & 5 & 6 & 7 & 8 & 9 \\
\hline BIVALVIA & & & & & & & & & \\
\hline Acila insignis & + & + & + & + & + & + & - & - & + \\
\hline Alveinus ojianus & + & + & + & + & + & + & - & - & - \\
\hline Anisocorbula venusta & - & - & - & + & - & - & - & - & + \\
\hline Axinopsida subquadrata & + & - & - & + & - & - & + & - & + \\
\hline Cadella lubrica & - & - & - & + & - & + & - & - & - \\
\hline Callista brevisiphonata & - & - & + & - & - & + & + & - & + \\
\hline Callithaca adamsi & - & - & - & - & - & - & + & - & - \\
\hline Crenella leana & + & - & - & - & - & - & - & - & - \\
\hline Crenomytilus grayanus & + & - & - & + & - & + & + & - & + \\
\hline Diplodonta semiasperoides & - & - & - & + & - & - & - & - & - \\
\hline Dosinia japonica & + & - & - & + & + & - & - & - & + \\
\hline Felaniella usta & - & - & - & - & - & - & - & - & + \\
\hline Gari kazusensis & - & - & - & + & - & - & - & - & - \\
\hline Glycymeris yessoensis & - & - & - & - & - & - & + & - & - \\
\hline Hiatella arctica & $\begin{array}{c}- \\
+\end{array}$ & - & - & - & - & - & + & - & $\overline{-}$ \\
\hline Leionucula ovatotruncata & - & - & + & - & - & - & + & - & - \\
\hline Liocyma fluctuosa & - & - & - & - & + & + & - & - & + \\
\hline Macoma calcarea & - & - & - & - & - & - & - & - & + \\
\hline Macoma golikovi & - & - & - & - & - & - & + & - & - \\
\hline Macoma nipponica & - & - & - & + & + & - & + & - & + \\
\hline Macoma orientalis & - & + & - & + & + & + & - & + & - \\
\hline Macoma sp.? & - & - & - & + & - & - & - & - & - \\
\hline Mactra chinensis & - & - & - & - & + & - & - & - & - \\
\hline Mactromeris polynyma & + & - & - & + & - & + & - & - & - \\
\hline Mercenaria stimpsoni & - & - & - & -- & - & - & + & - & + \\
\hline Mizuhopecten yessoensis & - & - & - & - & - & + & + & - & - \\
\hline Modiolus kurilensis & - & - & - & - & - & - & + & - & - \\
\hline Musculista senhousia & $\begin{array}{c}- \\
-\end{array}$ & $\begin{array}{l}- \\
-\end{array}$ & $\begin{array}{c}- \\
-\end{array}$ & $\begin{array}{l}- \\
-\end{array}$ & $\begin{array}{l}- \\
-\end{array}$ & $\begin{array}{l}+ \\
-\end{array}$ & $\begin{array}{l}+ \\
+\end{array}$ & $\begin{array}{l}- \\
-\end{array}$ & $\overline{-}$ \\
\hline Musculus laevigatus & - & - & - & - & - & + & - & - & - \\
\hline Mya arenaria & - & - & - & - & + & + & + & - & - \\
\hline Mya priapus & - & - & - & - & + & + & + & - & - \\
\hline Mya pseudoarenaria & - & - & - & - & + & - & - & - & - \\
\hline Mya sp. & - & - & - & + & - & - & + & - & - \\
\hline Mya sp.juv. & - & - & - & - & + & - & - & - & - \\
\hline Nipponomysella obesa & - & - & - & + & + & - & + & - & - \\
\hline Odontarina filatovi & - & - & - & - & - & + & - & - & - \\
\hline Peronidia venulosa & - & - & - & - & - & - & + & - & - \\
\hline Peronidia zyonoensis? & - & - & - & + & - & - & - & - & $\overline{-}$ \\
\hline Pillucina pisidium & - & - & - & - & - & - & $\begin{array}{l}+ \\
+\end{array}$ & - & + \\
\hline Raeta pulchella & - & - & $\begin{array}{c}- \\
+\end{array}$ & $\begin{array}{l}+ \\
+\end{array}$ & + & + & $\begin{array}{l}+ \\
+\end{array}$ & - & - \\
\hline Retusa succincta & - & - & + & $\begin{array}{l}+ \\
+\end{array}$ & - & - & + & - & - \\
\hline Solen krusensterni juv. & _- & - & - & $\begin{array}{l}+ \\
+\end{array}$ & - & - & $\begin{array}{c}- \\
+\end{array}$ & - & - \\
\hline Spisula sachalinensis & - & - & - & $\begin{array}{l}+ \\
+\end{array}$ & $\begin{array}{c}- \\
+\end{array}$ & $\begin{array}{c}- \\
+\end{array}$ & $\begin{array}{l}+ \\
+\end{array}$ & - & - \\
\hline Thracia myopsis & - & - & - & - & + & - & + & - & + \\
\hline Thracia septentrionalis & _ & _ & _ & + & - & _ & - & _ & - \\
\hline Tridonta borealis & _- & _- & _ & + & _- & _- & _- & _ & + \\
\hline Venerupis philippinarum & - & - & - & + & - & - & - & - & - \\
\hline Yoldia keppeliana & - & - & - & - & + & - & - & - & - \\
\hline
\end{tabular}


GASTROPODA

Bela erosa

Boreotrophon candelabrum

Cryptobranchia kuragiensis

Cryptonatica janthostoma

Derjuginella rufofasciata

Epheria turrita

Erginus puniceus

Erginus sybariticus

Homalopoma sangarense

Limalepeta lima

Lirularia iridescens

Lirularia minima

Lirularia picturata

Lunatia pila

Odostomia exarata

Olivella borealis

Onoba sp.

Philine scalpta

Propebela golikovi

Pusillina plicosa

Setia candida

Teinostoma atomaria

Turbonilla multigyrata

POLYCHAETE

Ammotrypane acuminata

Ampharete acutifrons

Ampharete lindstromi

Ancistrosyllis bassi

Anobothrus gracilis

Apoprionospio nova

Arabella iricolor

Armandia brevis

Asabellides sibirica

Asychis gotoi

Axiothella catenata

Brada villosa

Chaetozone setosa

Chone ecaudata

Cistenides granulata

Cistenides soldatovi

Dipolydora cardalia

Dorvillea japonica

Drilonereis filum

Drilonereis longa pacifica

Eudistylia chiaochouensis

Eupolymnia robusta

Glycera capitata

Glycera nicobarica

Glycera onomichiensis

Goniada maculata

Hyboscolex pacificus borealis

Laonice cirrata 
Lepidonotus squamatus 2013, Vol. 4, No. 1

Lumbrineris bifurcata Lumbrineris inflata Lumbrineris japonica Lumbrineris longifolia Lumbrineris minuta Magelona berkeleyi Magelona longicornis Magelona sachalinensis Maldane sarsi Mediomastus californiensis Melinna elisabethae Neobocardia perata Nephthys caeca Nephthys californiensis Nephthys longosetosa Nereis longior Nicolea zostericola Nicomache lumbricalis Nicomache minor Onuphis iridescens Onuphis shirikishinaiensis Ophelia limacina Owenia fusiformis Pectinaria dimai Pherusa plumosa Pholoe minuta Pilargis berkeleyi Praxillella gracilis orientalis Prionospio multibranchiata Prionospio steenstrupi Pseudopotamilla reniformis Sabella spirobranchia Scalibregma inflatum Scolelepis aff. texana Scoloplos armiger Spio filicornis Spiophanes bombyx CUMACEA

Brachydiastylis $s p$.

Campylaspis crispa

Cumella kepeli

Diastylis alaskensis

Diastylis bidentata

Diastylis paralasesis

Eudorelopsis leuconi

Lamprops affinis

L.quadriplicata longispina Lamprops multifasciata Lamprops sarci

Mezolamprops japonica ISOPODA 
Gnorimosphaeroma ovatum

Lynidotea epimerata

Paranthura japonica

Rocinela maculata

Synidotea brazhnikovi

Synidotea epimerata

Tachyrhynchus erosus

Tecticeps glaber

ECHINODERMATA

Amphiodia fissa

Amphipholis kochii

Aphelasterias japonica

Apoda sp.

Asterina pectinifera

Cucumaria calcigera

Chirodota pellucida

Echinarachnius parma

Echinocardium cordatum

Eupentacta fraudatrix

Lysastrosoma anthosticta

Ophiura sarsi

Patiria pectinifera

Scaphechinus mirabilis

Strogylocentrotus sp.

$S$. intermedius

Synallactes chuni

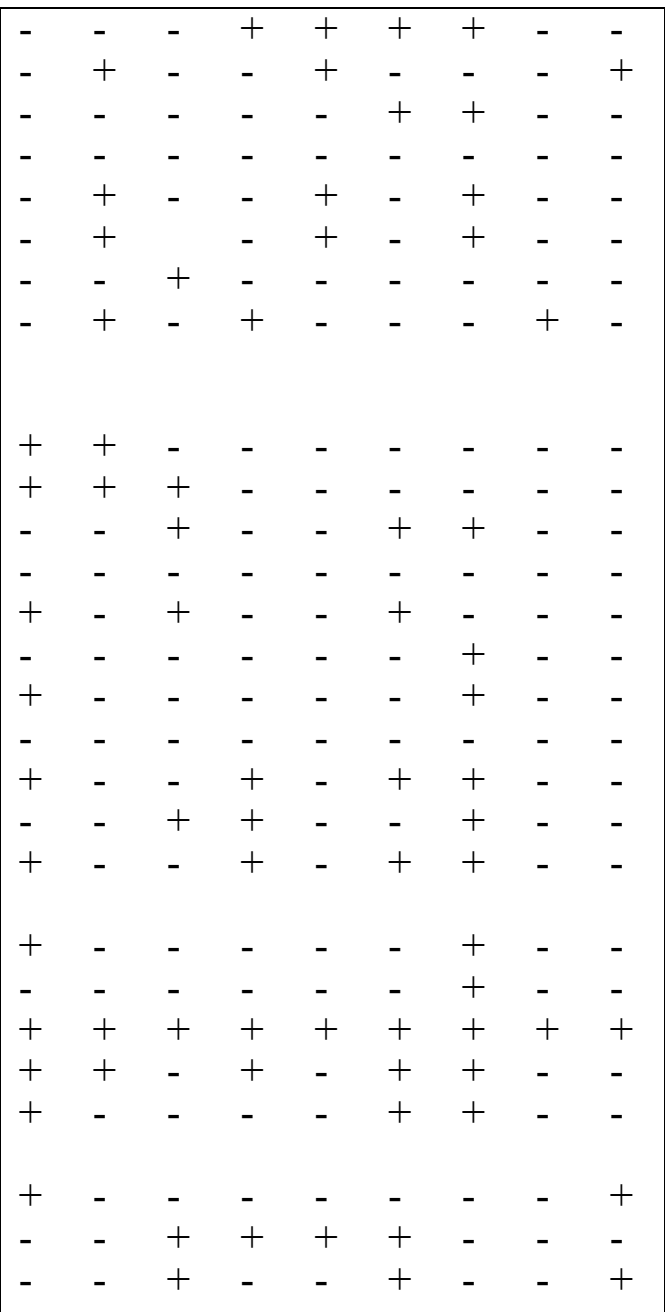

1-bay Astafieva, 2-bay Gorshkova, 3- island Bol'shoi Pelis, 4 - bay Sivuch'ya, 5 - bay Srednyaya, 6 - island Furugelm, 7 - Islet Fal'shivyi, 8 - bay Nerpich'ya, 9 - island Stenina

Explanation of figures

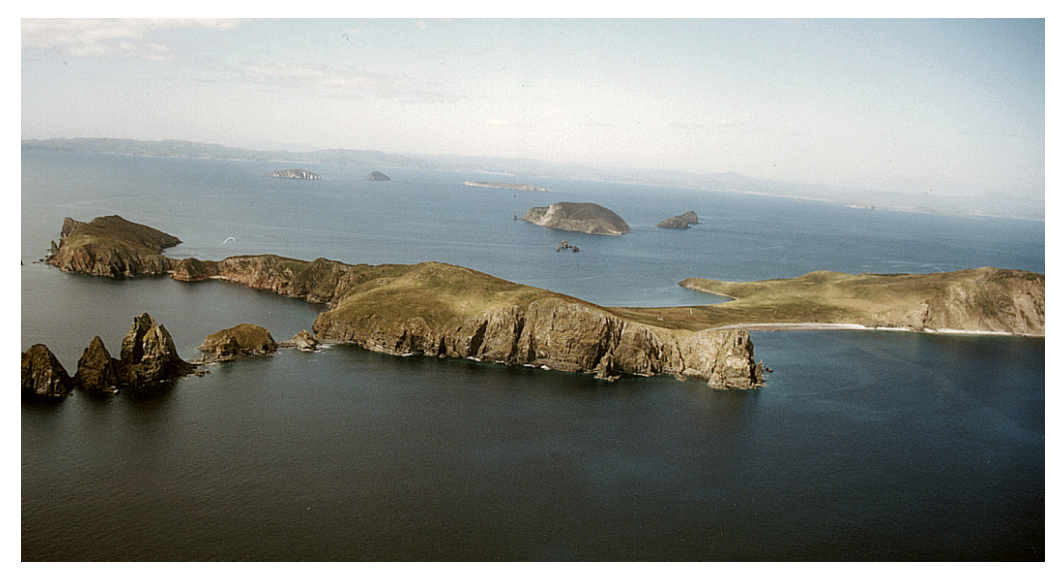

Figure 1. Island Bol'shoi Pelis 


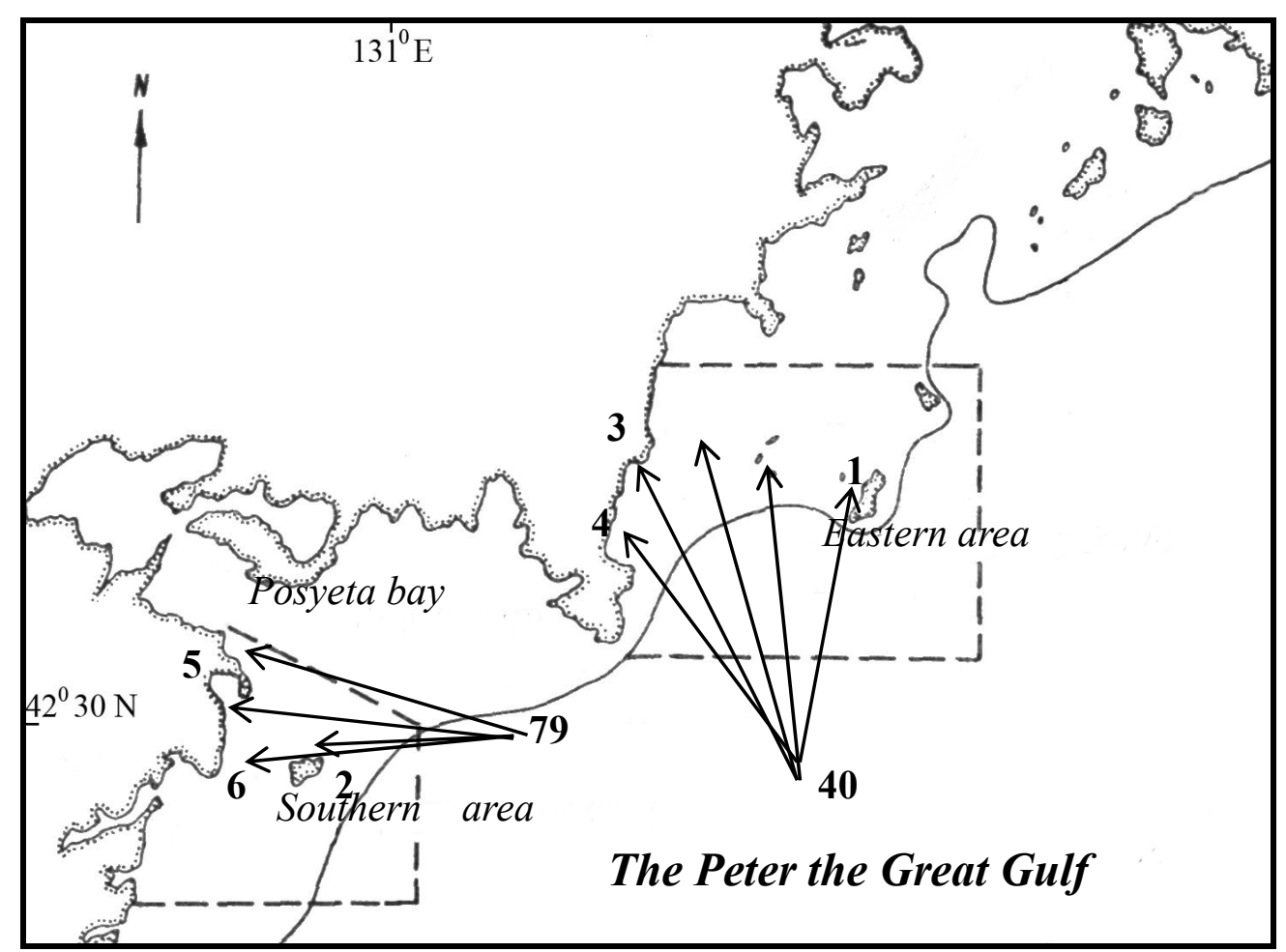

Figure 2. Skeleton-chart of the waters area of the Marine Reserve (dotted lines) and places sampling: 1- island Bol'shoi Pelis, $\mathbf{2}$ - island Furugelm, the numbers, 3, $\mathbf{4}$ and $\mathbf{5}$ - bays Astaf'eva, Srednyaya and Sivuch'ya, accordingly, 6 - Islet Fal'shivyi, (data 40 and 70) correspond to the number stations and sections

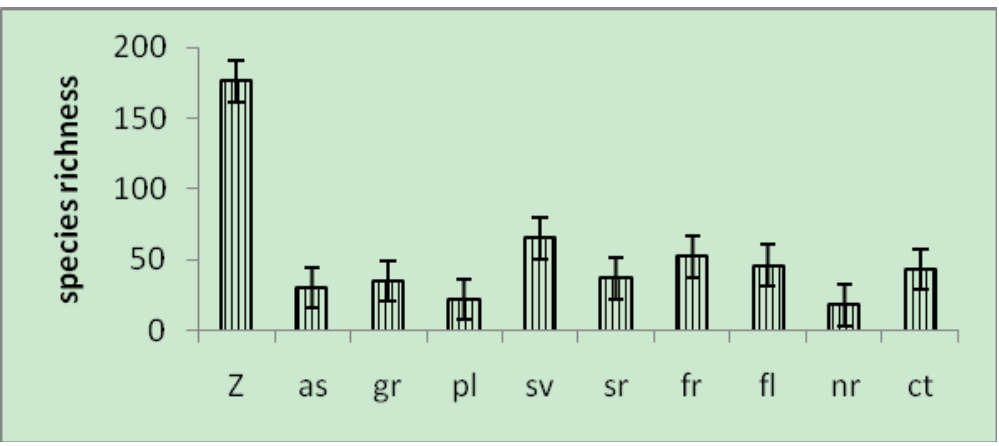

Figure 3. Species richness of macrobenthos of soft soils in Marine reserve and adjacent areas. $\mathrm{Z}$ is the total number of species, as - bay Astafyeva, gr - bay Gorshkova, pl - island Bol'shoi Pelise, sv - bay Sivuch'ya, sr - bay Srednyaya, fr - island Furughelm, fl - Islet Fal'shivyi, nr

- bay Nerpich'ya, st - island Stenina 


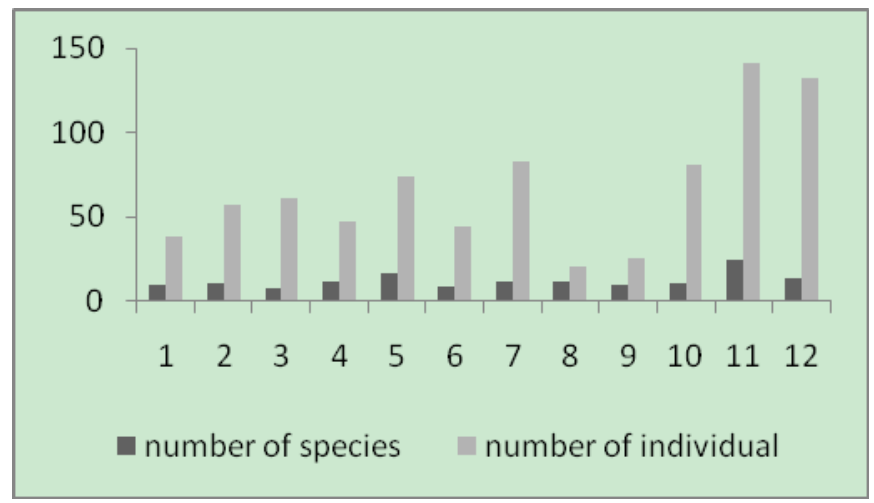

Figure 4. The ratio of the number of species and individuals in various areas of the samples. 1-3 -bay Astafieva. 4 - bay Bojsmana, 5-6 - island Bol'shoi Pelis, 7 - bay Sivuch'ya, 8-9-10 Stenina island, 12 - island Furughelm

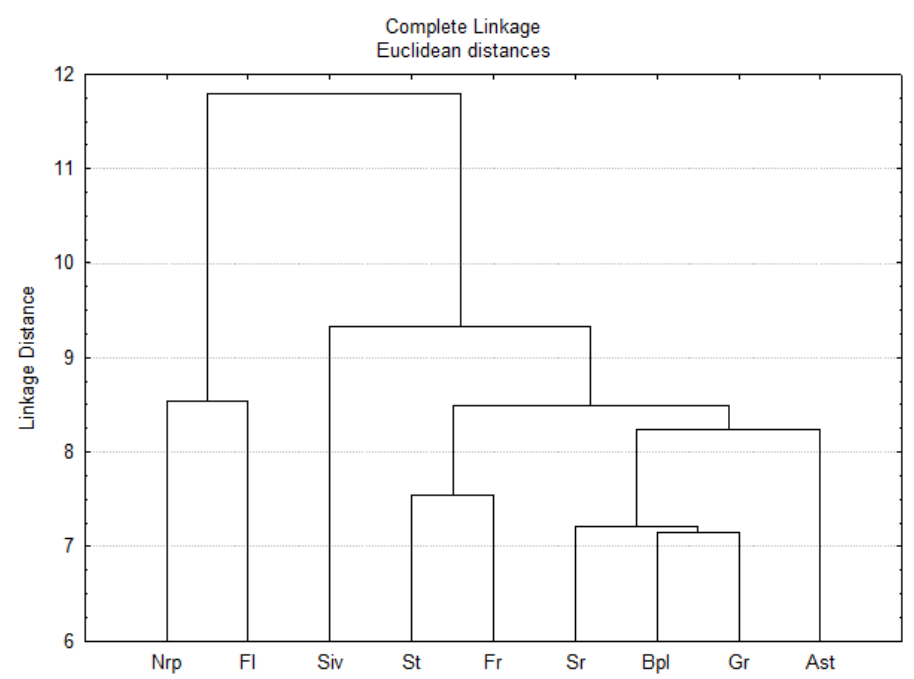

Figure 5. The level of similarity of benthic communities. Islands and bays: Nrp - Nerpich'ya, F1 - Islet Fal'shivyi, Siv - Sivuch’ya, St - Stenina, Fr - Furughelm, Sr - Srednyaya, Bpl Bol'shoi Pelise, Gr - Gorshkova, Ast - Astafieva 